\title{
The Dual-Gate Lumen Model of Renal Monoamine Transport [Expression of Concern]
}

\author{
Hinz M, Stein A, Uncini T. Neuropsych Dis Treat. \\ 2010;6:387-392.
}

The Editor-in-Chief and Publisher of Neuropsychiatric Disease and Treatment wish to issue an Expression of Concern for the published article.

Concerns have been raised regarding the alleged undisclosed competing interests of some of the authors, and the level of information provided on methodology, study data and process of institutional ethical approval for the published article. Neuropsychiatric Disease and Treatment would like to alert readers of this while our investigation is still ongoing and we will provide an update following the conclusion of our investigation.

The authors have been informed of these concerns and of our investigation.

\section{Publish your work in this journal}

Neuropsychiatric Disease and Treatment is an international, peerreviewed journal of clinical therapeutics and pharmacology focusing on concise rapid reporting of clinical or pre-clinical studies on a range of neuropsychiatric and neurological disorders. This journal is indexed on PubMed Central, the 'PsycINFO' database and CAS, and is the official journal of The International Neuropsychiatric Association (INA). The manuscript management system is completely online and includes a very quick and fair peer-review system, which is all easy to use. Visit http://www.dovepress.com/testimonials.php to read real quotes from published authors. 